\title{
Career-story Interviewing Using the Three Anecdotes Technique
}

\author{
Jacobus G. Maree \\ University of Pretoria
}

Address correspondence to Professor Jacobus G. Maree, Faculty of Education, Aldoel Building F214, University of Pretoria, Pretoria, 0002, South Africa. E-mail: kobus.maree@up.ac.za

This article describes the value of using the Three Anecdotes Technique (TAT) during career-story interviewing. The TAT is a technique aimed at eliciting clients' three earliest memories to help counsellors identify clients' preoccupations and thereby support them to deal with problems they encountered in early life, that still influence them. The participant was a white South African woman in her mid-twenties who was frustrated in her current career and who sought career counselling to help her decide on a career path and redesign her life. The results suggested that the technique helped the participant confront the complexities of negotiating a career pathway after the intervention. She appeared motivated to realise specific goals for her career and life development: Deal with her current (problematic) career situation, decide on a career path and redesign her life. The TAT offers a promising strategy for career intervention counselling.

Keywords: career-story interviewing, Three Anecdotes Technique, post-modern career facilitation, narrative career facilitation, biographicity, narratibility, holding environment

Although much has been written about the use of early memories in counselling internationally (Hartung, 2010; Savickas, 1998; 2009a), less has been written about its use specifically in career counselling, particularly in (South) Africa. This article is an attempt to address this situation.

Porfeli (2003, p. 300) maintains that "a gulf exists between career counselling and empirically based career theory and research. Practitioners argue that current research is too far removed from the client's subjective experience, whereas researchers argue that practitioners use antiquated instruments and obsolete career orientations in an attempt to resolve contemporary practice". Savickas (2006a, 2006b, 2007, 2008, 2009a, 2009b, 2009c, 2009d) first blended the psychodynamic approach with differential and developmental approaches to create an overarching, elegant and user-friendly approach to career counselling for life designing. According to Savickas (2007, p. 2), "it is important that counselors facilitate meaning-making as they exercise narrative competence in validating client stories and apply biographical reasoning in positioning those stories in [a] social context". He adds that

new life should be breathed into career counseling models by examining the poetics of personhood and the politics of work [and counsellors should design] innovative methods to help clients shape their stories and attune them to the work world [on the one hand] and shape the story of the career services profession itself by showing how, in the global economy, stories supply a sense of continuity, coherence, and commitment (Savickas, 2007, p. 3).

Savickas (2007) stresses the fact that stories are improved by good listeners. It is against this background that the present research was undertaken to build on the work of Savickas and others elsewhere in the world in an attempt to 'breathe new life' into career counselling strategies locally and to add to the growing body of literature on the use of qualitative (storied, post-modern) approaches to career counselling from a loca perspective. Early memories, which appear to be suitable mechanisms to reveal essential facets of a person's life struc- ture and career adaptability, are discussed briefly in the next section.

\section{Use of Early Memories: Brief Theoretical Background}

Although the use of early memories in career counselling is not new, it was Savickas (2007) who blended the psychodynamic approach with differential and developmental approaches to create an overarching and user-friendly approach to career counselling. In doing so, Savickas (2007) developed an approach to career counselling that counselors could use to help clients find meaning in life as they draw upon their life stories (apply biographical reasoning) to find holding environments and achieve success in life. Facets of the psychodynamic, differential and developmental approaches, which underpin the use of early memories, will be discussed next.

Adlerian perspective. Adler (1932) maintained that there is no such thing as "chance" memories, and that early memories represent the stories of clients' lives. Clients repeat stories to themselves to warn or comfort themselves, to keep themselves focused on their goals and to prepare themselves through revisiting (drawing advice from) past experiences to meet the future with a proven plan and style of action. He comments as follows on the use of early memories in career counselling: "If ever I am called on for vocational guidance, I always ask how the individual began and what he was interested in during his first years. His memories of this period show conclusively what he has trained himself for most continuously: they reveal his prototype and his underlying scheme of apperception" (Adler, 1932, p. 144).

Psychodynamic perspective. Saul, Snyder, and Sheppard (1956) argued that a person's earliest or first memories relate to isolated and seemingly fragmented recollections. These memories usually precede the beginning of continuous remembering and provide pointers to a person's key dynamics. Arguing that early memories should always be taken seriously and are always significant, these authors conclude that the earlest memories are probably the most powerful mechanism 
for discovering and unravelling traumatic events and their after-effects in life.

In my own counselling experience, I can recall few people who remember meaningful events before the age of four. However, it is not entirely uncommon to encounter clients who remember events that occurred at the age of two. Saul et al. (1956) maintain that first memories are sometimes accurate, sometimes distorted and sometimes consist of hearsay:

Earliest memories are absolutely specific, distinctive, and characteristic for each individual; moreover, they reveal, probably more clearly than any other single psychological datum, the central core of each person's psychodynamics, his chief motivations, form of neurosis, and emotional problem ... it seems that the major unconscious motivations select (author's own emphasis) those memories which fit them, just as the interplay of emotional forces which generates the dream selects just those events and memories which fit their needs for expression (p. 228).

Although earliest memories may often be inaccurate and even untrue, this does not mean that they are meaningless. Quite the opposite:

[Even if they] do not fit precisely, [they] are subject to distortion by the same processes which distort other events for use in dreams. Early memories ... exist for the service of the basic biological motivations of the life cycle ... are retained to serve present needs [and are] of the same nature and structure as dreams ...; they are selected just as the dream is formed, by the major motivational forces of the personality; they are selected (author's own emphasis) just as day residues are chosen for the dream, by the same forces; and when they do not fit accurately, they are distorted by these forces to fit and express the person's nuclear emotional constellation, and if something the person has been told fits well enough, then it may take its place as though it were an actual memory" (Saul et al., 1956, pp. 228-9).

It is clear from the above that careful reflection on and analysis of a client's early memories present counsellors and client with potentially useful information regarding early life problems that still influence the client, as well as regarding possible solutions for present-day problems. Counsellors might therefore utilize early life memories to help clients understand themselves better and use this as a platform for career counselling, or even therapy. Some of the advantages of the use of early anecdotes will be discussed in the next section.

Advantages of using anecdotes. Yapko (2003) contends that the use of anecdotes (by both counsellor and client) in counselling has several major advantages: anecdotes are non-threatening and engaging, they foster independence (clients need to make sense of the message and then come to a self-initiated action), and they can be used to bypass natural resistance to change and to control the relationship; clients cannot use their habitual means of controlling relationships when they share or listen to an anecdote. In addition, anecdotes model flexibility, subtlety and creativity, and can be used to tag (attach a label to) the memory and, in doing so, they make the presented idea more memorable.

Functions of anecdotes. Anecdotes are thus often used in therapy by either counsellors or clients to make or illustrate a point or suggest solutions, to assist clients to recognise themselves, to seed ideas and increase motivation, to embed directives, to decrease resistance and to reframe and redefine a problem (Cronjé, 2010; Yapko, 2003). According to Hartung
(2007), career counsellors use metaphorical language in dramatic form, after which they move from assessment to intervention by gently guiding clients towards reflecting on and interpreting their stories in articulate and interconnected narratives.

Importance of early memories in career-story counselling. Savickas (2006a) made the following comment about the significance of early memories, "[t]he whole is in every piece". In other words, these memories serve as our psychological DNA. Savickas (2009a, b) agrees that the subconscious deliberately chooses memories that are considered useful to the client at any given point in time and that they will therefore change over the course of time. Misleadingly simple on the surface, these unembellished stories (memories) are, in fact, deeply profound and can help counsellors identify clients' pre-occupations and thereby support clients in "actively master[ing] what they have passively suffered". Clients continually attempt to make up for what they suffered or missed during childhood. We, as counsellors, strive to be 'useful' to them as they turn their symptoms into strengths first and then subsequently into social contributions. Consistent with what counsellors are taught in story-writing workshops, clients' stories only start when things go wrong stories after all, are about what went wrong (otherwise there would be no stories!). Counsellors need to identify these 'twists' in clients' tales and to be of use to clients as they attempt to negotiate transitions in their lives.

Identifying life themes. When counsellors listen to clients' stories, they have to identify the major life themes in these stories. Every story has linear incidents (plot) and underlying themes (timelines). Counsellors have to identify clients' pain and pre-occupations, and, by carefully analysing these memories (stories), they can help clients elicit the themes in their stories.

According to Savickas (2009a, 2009b, 2009c), clients' current career counselling questions (problems) have to be fitted into the larger pattern of meaning that they live. In other words, these questions inevitably relate to and are embedded in clients' pervasive life themes (which are evident from their life stories or autobiographies). Counsellors need to teach clients the skill to draw upon autobiographical reasoning when they make a change in their lives - that is, use their own story to 'hold' (take care of/nurture/foster) themselves.

Creating a holding environment. Savickas (2009a, 2009b) explained that the original meaning of the word 'career' is 'care' and not 'path' (its second meaning). While our parents (mothers in particular), our home, our school and our university provide us with holding environments early on in life, we must eventually 'hold' ourselves and use career as a carrier of meaning (something that helps people find meaning in their lives) during times of transition to facilitate continuity in a fragmented world.

Narratibility. Savickas (2009a, 2009b) asserted that people draw on autobiographical reasoning when they make a change in their lives. In other words, they use their own stories to 'hold' themselves. This process is referred to as narratibility, and it is about clients' ability to say who they really are. The extent to which people can narrate the meaning of their lives gives an indication of how much of what they do will matter to others. A counsellor's main aim is therefore to help clients narrate and listen to their own stories.

Biographicity. Counsellors have to be 'useful' to clients as they identify their life themes so that they can use work to become more whole. Savickas (2009a, 2009b, 2009c) coined the 
term 'biographicity' to signify clients' ability to use their own stories to negotiate transitions. 'Biographicity' also denotes clients' capacity to use their stories as holding environments when life imposes changes on them.

\section{Purpose of the Study}

The aim of this case study was to investigate the usefulness of the Three Anecdotes Technique (TAT) during career-story interviewing. The study sought to answer the following questions:

a. How can the TAT in career-story interviewing be implemented practically with a young woman who seeks career counselling?

b. How can counselors facilitate clients' reflection on and analysis of their early life stories in such a way that career and life counselling is promoted?

c. Can the use of the TAT in career-story interviewing contribute meaningfully to change in the life of a young woman who seeks career counselling and help her take responsibility for her own actions?

\section{Method}

\section{Participant and Context}

The participant was a purposefully selected (McMillan \& Schumacher, 2001) young woman (Jane - a pseudonym). Jane volunteered to act as the participant ('client') during a live presentation. At the end of this type of presentation, three attendees are usually asked to tell the audience what the participant's story means to them personally. (The ethical considerations followed in this study are discussed later in the article.) The selection criteria called for a person who experienced a need for career counselling and was willing to volunteer as the 'client' in a live demonstration during a two-day workshop on career construction counselling for life designing presented by the author of this article (an element of convenience sampling thus also characterised the sampling style).

Jane, a 26-year old woman is unsure about her current occupation. An administrative official, she initially entered the corporate environment hoping to become a human resources manager. However, this dream has not been realised as yet, which has contributed to her feelings of confusion and 'failure'. She consults a career counsellor specifically wanting to know whether she should change careers (something she has been considering for a while), perhaps resigning from her current job and moving into private practice as an educational psychologist.

\section{Mode of Inquiry}

The study was based on an interpretivist paradigm (Denzin \& Lincoln, 1998) involving understanding and interpreting meanings as they are revealed during interactions. The research design was qualitative (Creswell, 2007; Durrheim, 1999) in nature as it was based extensively on a case study approach (McMillan \& Schumacher, 2001; Nieuwenhuis, 2007; Whitley, 2002).

The intervention incorporated post-modern career facilitation techniques (Maree, 2007) to enhance the involvement of the participant in her career construction process and to facilitate co-constructive conversation. Qualitative data sources were (i) observation (Cohen, Manion, \& Morrisson, 2000; Terre Blanche \& Kelly, 1999) by the researcher, which was documented in field notes and a research diary (McMillan \& Schumacher, 2001), (ii) formal and informal conversationaldata during the interaction between the participant and researcher, which were recorded and transcribed, and (iii) the participant's journal in which she reflected upon her experience of the sessions. The initial session was followed by two further personal meetings between the researcher and participant to clarify any possible misunderstandings. In between these sessions, the researcher emailed copies of transcriptions of the conversation to the participant for purposes of validation. This process was repeated until the participant confirmed the correctness of the data.

The data gathering strategy that was followed is explained below. (Due to space constraints, I do not report on or integrate all the data into the results.)

\section{Data Gathering Strategy}

Creating a sacred space first. Savickas (2006a, 2006b) stresses the importance of carrying out this procedure to make participants feel safe first - creating a 'sacred (safe) space' between counsellors and participants, and only then inviting participants to share their early recollections ('secrets') with the counsellor. The career-story interviewing process (Table 1) was therefore completed first, after which the TAT was used to augment the career-story interviewing process.

Eliciting three early anecdotes. Savickas (2006a) proposes the following questions to elicit three early memories: "What is the first thing you remember about your life? What are your earliest recollections? I am interested in hearing three stories about things you recall happening to you when you were 3 to 8 years old".

\section{Data Analysis Strategy}

Whatever the participant says should be carefully noted and written down. The first verb used is of special importance because it indicates action and how the participant moves in the world. The counsellor invariably revisits this verb at the end of the session. Newcomers to this type of counselling are advised to focus on the first verb as it represents a concrete strategy to provide novice therapists with some structure and build their confidence.

Repeated words, phrases or expressions should also be noted because they offer important clues about clients' life themes. After the clients have told their stories, the counsellor says: "Now let's pretend that each of these stories will appear in tomorrow's newspapers. Each story will have a headline. Each headline will have a verb. I want you to write this headline". Savickas (2006a) acknowledges, however, that some clients may not be able (or willing) to share their earliest memories and may instead prefer to talk about things that happened later in their lives. In such cases, it is best to proceed with these later memories.

During feedback, which typically starts with a discussion of the client's early recollections ('secrets'), the counsellor points out that although these memories (the recollections or secrets) may seem superficial, they are full of meaning and represent the client's advice to himself/herself. The counsellor stresses that these memories or stories reveal life-long themes: "It seems your first story has a theme of deep disappointment". Or, perhaps: "A theme that I have heard in your other stories as well suggests you are an independent, creative person". Another way of facilitating the discussion may be to say: "Your first headline suggests a particularly important theme: your commitment to the cause of the underdog". Or something like the following: "Likewise, your second story summarises your mission in life, which seems to be the desire to help others. No matter what you 
Table 1

\section{Career-story Interview}

a. How can I be useful to you as you construct your career?

1. Role models

Whom did you admire when you were growing up?

2. Magazines/ TV shows

What magazines do you read regularly? What television shows do you really enjoy?

3. Movies/Books

What is your favourite book or movie? Recount the story.

4. Mottos

What is your favourite saying or motto? Recount a saying you remember hearing or create one.

5. Play/Leisure

What do you like to do with your free time?

6. School subjects

What were your three favourite subjects in junior high school and high school?

7. Three Anecdotes Technique

What is the first thing you remember about your life? What are your earliest recollections? I am interested in hearing three stories about things you recall happening to you when you were three to eight years old.

Source: Mark Savickas (1998, 2009); Paul Hartung (2007, 2010)

do, you will always want to help others. You see, in your career you need to do what you have been rehearsing all your life. That is who you are, that is what you have to do".

Making sure that clients hear what they tell themselves: repeating clients' own words. Clients' own words and expressions are repeated frequently by the counsellor, and clients should be prompted to say these words and expressions out loud because the more they say them out loud, the more the words and expressions will become actual to them. When clients express fear or anxiety, for example, they are reminded that this proves only how brave or bold they are for admitting the anxiety, and that one can only become stronger at something at which one is weak.

Starting the feedback session. The career-story interview is typically concluded by asking the participant to return to the counsellor's first question: "How can I be useful to you?" The counsellor reads the participant's response back verbatim, contextualises it and asks the participant if his or her initial request has been addressed satisfactorily. Counsellors should ensure that participants not only listen to themselves but actually hear what they are saying to themselves. In other words, counsellors should repeat to participants what they have said and refrain from any interpretation themselves so that the participants can, firstly, hear and internalise and, secondly, live what they themselves have said. In other words, counsellors should let the words echo in the participants' minds (Savickas, 2009a, 2009b). Showing respect to participants is of overriding importance. Counsellors should continually endeavour to uncover the implication of what participants are saying, and they should therefore continually seek clarification: "What you have said - what does it mean to you? Did I hear you correctly? Did I understand you correctly? Did I misstate what you said?' (Savickas et al., 2009).

Observing participants: "The body never lies." Savickas $(2009 a, b)$ stresses the importance of observing participants closely the whole time, noting bodily changes, remarks, sighs, shifts in the position of the body, direction of the gaze, and so on. In his words: "The body never lies" (Savickas, 2009b). Bodily movements and other non-verbal cues are extremely helpful in 'reading' participants and being useful to them as they interpret their stories. These observations need to be incorporated into the counselling and other information. Counsellors may for instance wish to verbalise these observations in the following manner: "You are smiling/ frowning/ sighing?", thereby implicitly inviting clients to reflect on these observations.

\section{Ensuring the Trustworthiness of the Study}

The trustworthiness of the study was ensured through the use of various strategies during the data collection and analysis phases. Table 2 lists these strategies.

\section{Ethical Issues}

Measures to ensure the research participant's wellbeing were implemented throughout the study. At the end of this type of presentation, three attendees are often asked to tell the audience what the participant's story meant to them personally. Attendees are reminded of the ethical issues involved: No person is allowed, for instance, to invade a participant's privacy by, for example, discussing the case with anyone else. Informed consent was obtained from her, and confidentiality was maintained. She gave written permission for the publication of the case study on condition that anonymity was ensured. I, as the researcher, provided her with written feedback during all the phases of the inquiry, and the research findings were released in an acceptable and responsible manner (Whitley, 2002).

\section{Results and Discussion}

\section{Career-story Interview}

Jane's answers to the questions posed in the career-story interview (Hartung, 2010; Savickas, 2009a, 2009b) are given below (the verbatim responses have been only lightly edited to preserve the authenticity of what they say):

Introductory question. Jane's responses to the CounselIor's (C) question "How can I be useful to you as you construct your career?" appear below.

Participant $(P)$ "I have come to a crossroads in my life. I studied educational psychology but for various reasons ended 


\section{Table 2}

\section{Strategies to Increase and Enhance Trustworthiness during Data Collection and Analysis}

\begin{tabular}{|c|c|c|}
\hline \multirow[t]{5}{*}{ Credibility } & Multi-method strategies & $\begin{array}{l}\text { Triangulation - Many types of evidence were collected for diverging } \\
\text { and converging of evidence (Golafshani, 2003; Stake, 2005). }\end{array}$ \\
\hline & Peer debriefing & $\begin{array}{l}\text { Crystallisation }{ }^{1}-\text { The focus was on the complex patterns and themes } \\
\text { that emerged during the data collection. }\end{array}$ \\
\hline & Participant review & $\begin{array}{l}\text { Continuous observation of the participant was carried out during the } \\
\text { interview. }\end{array}$ \\
\hline & & $\begin{array}{l}\text { All data were coded independently by an external coder in order to } \\
\text { ensure that the identified themes were an accurate representation of } \\
\text { the data. }\end{array}$ \\
\hline & & $\begin{array}{l}\text { The participant had the opportunity to determine whether the results } \\
\text { and inferences were accurate. Misunderstandings were cleared up } \\
\text { and/or concepts discussed with the participant before the data were } \\
\text { interpreted and analysed in order to ensure a comprehensive under- } \\
\text { standing of the phenomenon. }\end{array}$ \\
\hline \multirow[t]{4}{*}{ Dependability } & $\begin{array}{l}\text { Verbatim reporting of re- } \\
\text { sponses }\end{array}$ & $\begin{array}{l}\text { An audit trail was carefully maintained. Conversations and } \\
\text { semi-structured interviews, explanations and situations were re- } \\
\text { corded in detail and then transcribed. English was used as the me- } \\
\text { dium of communication. }\end{array}$ \\
\hline & $\begin{array}{l}\text { Low-inference explana- } \\
\text { tions: presentation of neg- } \\
\text { ative and/or contradictory } \\
\text { information }\end{array}$ & $\begin{array}{l}\text { Information was presented in as much detail as possible - also infor- } \\
\text { mation that could be considered as contradictory to the identified } \\
\text { themes. }\end{array}$ \\
\hline & Mechanical data gathering & All conversations were recorded. \\
\hline & $\begin{array}{l}\text { Selective use of data was } \\
\text { avoided }\end{array}$ & $\begin{array}{l}\text { The data were coded independently by an external coder in order to } \\
\text { enhance their accuracy. The external coder assisted in this regard }\end{array}$ \\
\hline Confirmability & $\begin{array}{l}\text { Selective use of data was } \\
\text { avoided }\end{array}$ & $\begin{array}{l}\text { The data obtained, the methods used and the decisions made during } \\
\text { the project were fully documented. }\end{array}$ \\
\hline Transferability & $\begin{array}{l}\text { Inferences had to be sup- } \\
\text { ported by sufficient evi- } \\
\text { dence }\end{array}$ & $\begin{array}{l}\text { Observations were documented in a research diary. } \\
\text { Detailed descriptions of the particular setting and the techniques } \\
\text { used were provided - sufficient information was given on the context } \\
\text { of events for readers to judge the applicability of the findings to other } \\
\text { known settings and to replicate the study. Inferences were made } \\
\text { only if they could be supported by the collected data. }\end{array}$ \\
\hline
\end{tabular}

Note: Compiled from Creswell, 2003, pp. 196-197; McMillan \& Schumacher, 2001, pp. 407-409.

${ }^{1} \mathrm{I}$ am aware that many researchers believe that triangulation and crystallisation should not both be referred to in one study. In following researchers such as Bar-On (2007, personal communication), Jansen (2007, personal communication) and Elias (2007, personal communication), I do, however, use both strategies in this study.

up in a corporate environment that I find highly disappointing, discouraging and non-supportive. My dreams are shattered, since this shift in career did not turn out the way I thought it would. Now it feels as if I'm stuck in a wrong choice, a 'mistaken' world that was important to me once. I made these 'mistaken' choices when I was still young and inexperienced. Looking back at the reasons behind this career move seems irrelevant and immature at present. I have not talked about this much, but, recently, I have started feeling that I am not doing what I was meant to do. Help me find the road again ... Should I turn left or right, go back or go on? Please give me guidance and direction to help me make a decision.

"Incidentally, three years ago I applied for admission to a master's degree programme in educational psychology. However, my application was turned down. I was profoundly disappointed and there and then decided to take up another appointment for which I had applied ... in human resources".
"I later returned to complete my master's degree studies in education (learning support, guidance and counselling). I did so because I was lead to believe that doing so would equip me with the skills to open a private practice as a remedial therapist and also that doing my doctoral degree in career counselling would enhance my chances of being admitted to a master's degree programme in educational psychology at a later stage".

The second question pertains to the client's role models.

Role models. Jane's responses to the question regarding the three persons she admired most when she was growing up, appear below.

"My Grade 1 teacher. She was an intellectual; she was elegant, happy and friendly, and she taught me how to learn, I mean read (she interrupts herself, coughs and swallows a few times) - she taught me new, valuable things ... how to read and do mathematics. My whole being wanted to be like her. She 
knew everything, it seemed, that I didn't know then. She loved us; being with her was such a pleasant experience".

"My second role model was an 18-year-old woman (I was six years old at the time). She was beautiful and made me feel confident about myself. She used to put make-up on my face and tried to make me look like her. People even said I looked like a younger version of her - she was like the older sister I never had. I just have a younger brother; oh, I actually meant to say older brother! It just feels as if he is a younger brother (once again, she interrupts herself, coughs and swallows a few times) ... Having been diagnosed with ADHD, he has always experienced multiple learning barriers. My second role model had such a beautiful handwriting (tears appear in her eyes). She really meant a lot to me because she acknowledged me, and I could talk to her and 'look' like her in a way. She provided me with an opportunity to actually have 'my very own identity"'.

"My third role model was my 'imaginary' biological mother, since I had not met her at that stage of my life. She was the one person that I so badly wanted to "look like" and physically take after. Since I can remember, I desperately wanted to look like someone. I remember that I had this idyllic idea of her - whenever I would think of her, I would picture her as being intelligent, attractive and successful. In my mind she was placed on a pedestal - someone I always looked forward to meeting in the future".

Next, Jane was requested to share information about her favourite magazines and television shows, and her responses to the question regarding who she admired when she was growing up, follow.

Magazines and television shows. "The You magazine. It relaxes me to page through the magazine; I enjoy looking at the beautiful faces. Reading it takes me to a world where nothing worries me. It is relaxing to look at other people's lives. I also enjoy reading Cosmopolitan. The magazine articles give excellent information on how to maintain relationships with others as well as on ways in which I can manage to live a healthy life. Lastly, I enjoy reading Oprah. The life stories of beautiful, elegant persons fascinate me. I enjoy reading about the very latest fashion developments. The articles in this magazine also contain relevant and current information on psychology topics. It has some academic value that you can learn from, but in an informal and laid-back manner".

The third question referred to Jane's three favourite movies and books.

Movies and books. "First of all, I am interested in different kinds of books. One is Vaselinetjie (sighs). This is the story about an orphan, Vaselinetjie, who was placed in an orphanage and eventually found someone she loved and who loved her in return. Despite being drawn apart by circumstances beyond their control, they eventually end up together again. It is also a sad story of drugs, abuse, suicide and a brothel; she was exposed to the ugly side of life and was left unprotected and vulnerable. A shocking sad and frightening story (sighs). She never had the opportunity to meet her biological parents and I can relate to that".

"My favourite movies also differ widely. One is The Green Mile. It is about people who are sentenced to death and spend their last days together in a prison corridor. One prisoner had the gift to take away a person's illness and give him/her back a 'healthy' life. He was eventually electrocuted for the murder of two children he did not commit. He was sentenced to death but, nevertheless, never became negative. Despite having been accused falsely, he always remained optimistic and pleasant. In fact, despite what happened, he still had a desire to help others and to heal them with the gift he was given to take away illness".

"The other book is about unconditional love. The farmer, who is a Christian, saves a woman from a life-threatening and destructive man. This woman was stunningly beautiful and desired by most men, and she was abandoned and sold to a brothel to work as a prostitute. This man took her away and cared for her and tried to convert her to Christianity. She frequently 'ran away' from him because she thought he was being polite and did not really love her (he did not expect any physical or sexual contact from her (the one thing men did want from her). He would then go after her and bring her back to protect her from the life she was used to. A loveless life. Eventually she was converted and dealt with all her fears and anxieties of abandonment and rejection and lived a loving life thereafter".

Jane was subsequently asked to recount three favourite saying or mottoes (or even a saying she remembered hearing, or to create her own saying or motto).

Mottoes. "The roots of education are bitter but the fruits are sweet'. This quotation kept me motivated throughout my university life and in troubled times on my academic journey, the third one? 'Treat others as you wish to be treated"'.

"This is what I tell myself in troubled times. 'This, too, shall pass'. I tell myself, 'you will overcome this'. Also, 'It is not who you are but who you know that matters'. After major disappointments in my life, I have come to the realisation that people do not acknowledge one for who you are and what you have achieved but instead only for who you know".

The fifth question to Jane was: What do you like to do with your free time?

Play/leisure. "I like camping; going out of the city. The beautiful scenery makes me humble, and I again appreciate everything. I feel free, not so stressed and worried. It is almost as if I enter a time-free zone where time is no longer relevant. This free time is very important to me because I am actually a very punctual person. I also enjoy sport (hiking and back-packing). I love the scenery; it is good to get my body working and restoring balance in my life. This is such a boundary-less experience; the feeling of being free from time and from responsibility. I enjoy this hobby because it gives me the opportunity to appreciate the surroundings and beauty and become 'one' with my creator".

"I also enjoy watching TV, especially movies that help me to escape and relax. Especially stories that are not grounded in reality, for example Lord of the Rings and animated movies".

The last of the six career-story questions dealt with Jane's three favourite subjects in junior high school and high school;

School subjects. "My favourite subjects at school were Technical Drawing, Physical Science and Art/Drama. Technical Drawing meant that I could construct something concrete and actually see the result. I was interested in architecture as a career, but could not pursue it for a number of reasons. I think about being an architect regularly, but that passion was 'replaced' with the second best option available-constructing people's lives through education and psychology. To this day, I wonder what life would have been like had I studied in this field. This may be the reason behind my career identity confusion".

"I remember my deep desire to become an architect since both my biological parents (according to child welfare) were artists and draftsmen. My father who raised and loved me is a building constructor, and I was always fascinated by this career - I believe the reason I wanted to pursue this career was to enable me to 'identify' with my biological parents in an 'abstract manner'. Furthermore, 
this career seemed like a career few women ever dared to follow. I like being different. The reason I did not enrol for this course was that the course had already closed by the time my submission form reached the university. They instructed me to enrol the next year. My mother suggested that I study teaching in the meanwhile. I wanted to enrol the following year, but due to financial difficulty and my father losing his job more than once, my parents could not afford this course. Luckily, the university offered bursaries in teaching for academic achievers, and that's why I committed myself to this degree".

"Physical Science had elements of harmony. However, I was always aware of the 'dangers' attached to the subject: unless one applied oneself in a professional and correct manner, you would not make it in this subject. After all, only a few persons completed this subject. Art and Drama represent two ways of expressing my innermost feelings".

"I did not enjoy languages because I always found it difficult to express myself. People would always critique one's use of language. Admittedly, I did enjoy the cultural side of languages. It provided me with a way of communicating with the world without being judged on account of my inadequate use of language, for example using the wrong tenses. I also did not enjoy Biology because it meant too much work. Not knowing how to study it, I decided to put it out of my mind".

Once the counsellor had managed to create a sacred space (make Jane feel safe) (Savickas, 2006, 2006a, 2006b) the TAT technique was applied.

Three earliest memories. Jane's responses to the counselor's last question, namely "What are the first things you remember about your life? I am interested in hearing three stories about things you recall happening to you when you were three to eight years old", are noted below. (The client was asked to recount each story first and then provide a title for that story.)

1. Dog-bitten girl soothes mother

"I was three and a half years old when this happened. A dog, not my own, although I knew it well and trusted it - a Doberman or Rottweiler, I cannot recall - bit me in the face and actually tore off my right ear. My mother picked me up and cried incessantly. I could see the worry in her eyes, and I consoled her as best I could: 'Mommy, please do not cry'. I still have a fear of dogs, even to this day. I remember I was more concerned about my mother crying than anything else. I was not aware of my ear at first, but I was immediately taken to hospital where I had my first experience of plastic surgery when my ear was stitched back. At the time, it felt as if the incident didn't bother me because I just continued with my life. Except for this fear of dogs, that is".

\section{Long-awaited meeting shatters lifelong dream}

"First, something that happened at the age of six (sighs heavily) entered the picture. I must stress the fact that I have always wanted to look like someone. I remember the day a classmate in primary school remarked: 'But you do not take after either your father of your mother at all. Funny that both of them should be so tall, whereas you are so short. In fact, your facial features are so vastly different from theirs!' I was terribly disappointed and, in fact, speechless, voiceless. And this happened time after time after that day. Now this is the big theme in my life. I have always badly wanted to look like someone".

"The next part of the story happened when I was 24 years old. I remember that my parents and I decided that it was time for me to meet my biological mother. I was requested to write a series of letters to the social worker who gave them to my bio- logical mother and vice versa. After a period of four months, the social worker decided that we were ready to be introduced to each other, and she set up a meeting between the two of us (silence). I was extremely disappointed, though, to observe that I did not look like her at all. I felt sorry that I had met her. It felt as if something had been taken away, something precious, a life-long dream that had been shattered".

3. Book illustrates painful truth

"This is a very difficult one (sighs; tears well up in her eyes). My parents told me from an early age what it means to be adopted; they wanted me and my brother to comprehend what they were saying and thus never kept it a secret. My Mom made an effort to read to me all the historical and personal information about each parent that was given to her by the social worker she would read this to me like a story and my imagination ignited on 'I wonder how she looks like, and do I take after her?' My biological mother also wrote me a letter to 'prove' or 'confirm' her love for me - but at the vulnerable age of 24 , I did not trust this letter as a source of love and acceptance any longer. When I was eight years old, my parents decided to give me a special gift, a book entitled Adoption is forever. They were calm and relaxed when they gave me this present, and they used to read to me from this book and discuss all issues with me and my brother. I then suddenly gathered that my parents were not my real parents and that I might never get to meet my real parents. One very reassuring thought was that we are all adopted children of God - my parents always tried to 'normalise' this experience, and books were one of the ways in which they tried to communicate their unconditional love for me".

\section{Discussion of the Data and Data Analysis}

\section{Analysis of the TAT}

Jane's own - albeit elicited and facilitated - reflections on her stories follow between inverted commas.

Jane's response to the initial question (and the deep disappointment she expressed about her employer) reveals her current problem as well as her plan for solving the problem. She wonders if she should not find a different occupation, perhaps become an educational psychologist, so she could establish a 'new' identity. "Listening to myself, I am beginning to feel that I want to shake off the identity of 'rejection' and 'distrust'. I believe that remaining in my current job amounts to rejecting myself because I am denying my identity as an educational psychologist. In fact, I have to address the 'self-fulfilling prophecy' of rejection and stop allowing myself to remain in situations which 'allow' me to be rejected". Because she was 'betrayed' (a central life problem) early in her life, she is anxious to find her personal identity - another central life theme.

Jane's first verb is 'bitten'. She is bitten (betrayed) and hurt, which is what she is consulting the counsellor about. Wounded and hurt, she is unsure and worried about her future (in the corporate environment in which she finds herself) and how to move forward. (While Jane narrated these stories, I repeated the key phrases and words she used to ensure that she listened to herself carefully and actually heard herself saying what she was trying to say. In other words, I facilitated narratibility.)

When asked to reflect on her first story, Jane commented as follows: "I recently fell out badly with a woman that I work with and used to trust. She was promoted on several occasions and took it upon herself to damage my reputation among 'influential' people. In a way, I believe that I may be jealous of her promotions and hurt by her 'betrayal' and disrespectful actions". Jane 
'discovered' that she had been betrayed ('bitten') by a person or entity that she trusted ('dog'). Jane now realises that her current work environment was a great disappointment. "I was hurt because I feel that I am not being treated fairly and with due respect. I believe they won't give me an opportunity to prove my worth despite the fact that I am better qualified than all others in the corporation."

Jane's first memory (of a dog that bit her and of her mother who failed to console her) is therefore understandable: She discovered that the person who was supposed to soothe her in times of pain would not do so and, in fact, expected her (Jane) to assume the role of caregiver instead of being cared for by her mother from an early age onwards. She recently experienced the same disappointment and 'betrayal' in the corporate, working environment without receiving sympathy from anyone, and this experience prompted an appropriate early anecdote denoting a central life theme.

When asked to reflect on the second story, Jane commented as follows: "From the first day that I started working at the HR company, I wanted to become part of the human resource management department because this would bring me closer to what I had studied. The HR director advised me to gain more knowledge about what we as the company 'do'. So, for a year, I learned the inside and outside of what we 'do'. When I returned to the HR director, he advised me to get some sort of qualification in HR. I attended two courses and received an advanced certificate in HR management. This still was not "good enough'. He then suggested that I should get some worthwhile experience. The HR manager agreed to mentor me and expose me to HR to gain experience. After two and a half years of dedication and complying with their 'suggestions', I realised that there was no space for me in HR, and they could and would not assure me that there would ever be a vacancy, a space, an identity for me in the firm in the future. This has resulted in me 'giving up' on my dream and wanting to change careers".

Her second story therefore confirms her disappointment when she realised that she did not look like her mother (read: was not provided with an own identity by the corporate environment in which she worked). She desperately wanted to look like her, but, over time, she came to accept the fact that she did not look like any person at all. Moreover, the meeting did not result in any emotional bonding between the two. She then concluded that she had little choice but to construct her own identity; to get out of her "dream world and construct [her] own reality". Her growing concern that her current working environment had failed to provide her with a career and life identity was confirmed - at present, she feels 'identity-less' and at a crossroads.

When asked to reflect on her third story, Jane commented as follows: "Books and written language used to comfort me because these were 'objects' that contained my future and identity in written (and undeniable) format. Furthermore, these 'objects' had a permanency to them: I could consult them as often as I wished, and their message would always be truthful and not abandoning. Written messages help to bring the following point home: 'l'm not the only adopted person, and this is borne out by the fact that somebody had actually taken the time to write a book about adoption; this painful experience'. My experience with my adopted parents, a long time ago now, has taught me that the written word (books, written language) could be used to assist people in communicating painful news to others. This act potentially serves to 'normalise' painful truths".

In respect to her current working environment, she believed she had never been informed in writing about her future with the company. She had subconsciously been hoping for a 'positive' written communication, but nobody in the company ever took the trouble to explain the situation to her honestly. Furthermore, as had been the case in the past, oral communications turned out to be disappointing and rejecting of her. She interpreted HR management's failure to submit in writing the steps she needed to take to secure promotion (steps that would assure her of a permanent position in $\mathrm{HR}$ - and an identity) as "unspoken abandonment". The only written messages she received in her current context were "[h]urtful in a personal capacity. I now realise that both my mother and my current employees have disappointed me in this manner. This is sad because I used to trust a few things, and these include 'published' books because they contain undeniable truths out there for all to read, for example truths about adoption and belief. This makes me think of the book on adoption and the Bible".

In Jane's case, reading books was a substitute for dealing with pain through 'education' instead of just talking about pain When she was recently informed orally that all her training and further studies in HR were irrelevant (since there were no vacancies in the firm at present or would be in the future), she felt 'unacknowledged', 'identity-less' and deprived of opportunities to learn. Her working environment, which was disappointing and rejecting, re-ignited these painful, life-long themes in her.

\section{Follow-up}

Jane's message to herself was to move into a different, embracing [holding] environment. To achieve this goal, she needed to grasp the opportunity to enrol for a doctoral degree in learning support, guidance and counselling. This would afford her an opportunity to return to the safe and comforting world of books where no one could hurt her verbally on the one hand, and to 'prove' to herself that she had resolved her own language problems. She would be able to express her feelings in writing again, in a safe and accepting world, and open a private practice as a remedial therapist, career counsellor and psychometrist where she could help others express their innermost feelings, and deal with their distress verbally. She would thus be undoing what she had suffered. That is, dealing with the problem to make sense of the 'written word' and dealing with her deep and unresolved issues about her career and her perceptions about having been adopted.

Three months later, Jane reported to the counsellor that she had made up her mind about studying teaching and learning support (education) and that she had, in fact, been accepted into the doctoral programme in 2010. She had also decided to change careers by resigning from the corporate world and opening up a private practice as a remedial therapist, career counsellor and psychometrist, where she could help others deal with their learning and emotional problems. In her own words: "I am planning to make the move as soon as possible. The idea has been accepted $100 \%$; I just have to work out the details". (It should be mentioned at this stage that the researcher-counsellor had referred Jane to a clinical psychologist to help her deal with the unresolved personal issues (highlighted above) that emerged during the career-story interview).

Collectively, these two moves will hopefully provide a holding environment for Jane as she travels on her journey through life and faces various transitions. She is determined to 'overcome'; to draw on her autobiography in turbulent times to face difficult transitions in the years to come - thereby turning her pain into her triumph. 
Significantly, Jane twice failed to respond to the following question: "What is it that is preventing you from studying architecture? Conversely: If you were offered an opportunity to study architecture today, what would your choice be?" When she was alerted to this 'silence' on her part, she was surprised at first, but subsequently confirmed that her fear of rejection again had prevented her from considering that avenue. Furthermore, no matter which way she looked at it, architecture was not a 'realistic' option for a number of reasons, such as financial constraints and marks that were too low to gain acceptance into the discipline. This was nevertheless highlighted as an avenue that would require investigation in the future. Opportunities had to be found that would enable her to pursue architecture as a hobby perhaps and, in doing so, add meaning to her life.

\section{Discussion}

\section{Analysis of the Career-story Interview}

Virtually every answer to the questions posed during the life-story interview supports the reflections delineated in the preceding paragraphs. Her role models (Grade 1 teacher, 18-year-old woman) confirm her central life goal and her envisaged solution to her central life problem: she wants to be confident about herself as an intellectual who knows the answers to questions and who is beautiful. She believes that in the past she was often denied the opportunity to discover the 'truth' - her current job is, in fact, preventing her from entering the field of human resources. Jane believes that her 'obsession' to look like some other person is the reason she adored the beautiful 18-year-old woman: "All the 'makeup' and titivating sessions were important to me because I wanted to look like someone".

Another central life goal was to learn new things, but this was thwarted, too. Because she felt guilty about her brother's situation (see below), Jane felt, to a certain extent at least, that she did not have the 'right' to use the opportunity to learn as freely and as much as she would have liked to. "I am inclined to believe that my desire to learn new things is connected with my brother who cannot study: Whereas he has always excelled at practical activities, he has always experienced great difficulty to make sense of the "written word"'. He often reminded her of his desire to study the way she did, but he just could not make sense of anything written in books. "Furthermore, I know he also has deep and unresolved issues about his career and his perceptions about having been adopted. Could that also be the reason why he found studying impossible? I have always felt guilty because I had the ability and opportunity to study, which he did not have. I think I have always introjected his inability to study because of my own fear of being 'denied' the opportunity to learn".

Jane believes that the reason behind her correcting herself when the question about her brother's age was put to her was her feeling of being a 'failure' because of her poor choices: "Whereas he can be forgiven for not studying, given my level of education and knowledge of psychology, I should have known better. I believe correcting myself, is consistent with my need to be 'humble' and grateful. I believe I referred to my brother as 'younger than me' because I support him and sometimes provide for him. He looks up to me and I often feel like his 'older sister"'.

Her accounts of a book and a film involve major characters who are confronted by, and show her how to deal with, problems similar to her own. Her second favourite (movie) character is a loving, caring person who was wrongfully accused of doing something wrong; yet, he persisted in helping others despite the unjust manner in which he was treated. They are similar: this person, too, had the need and ability to help others. Slightly older now, Jane accepts the vicissitudes of life and hopes to achieve her goal of helping others deal with the pain she has suffered. Not unlike herself, her favourite character is brave and persevering, and has wisdom and a sense of what is right. Her favourite movie character, too, is prepared to give up his own personal comfort to achieve a greater goal, namely to be of service to others. She is prepared to sacrifice whatever is needed to 'overcome'. Her third favourite (a book) re-emphasises her need for "[s]ecurity, love, trust and belief in an Almighty God. This book which has a Christian slant, inspired me on a spiritual level and healed me in many ways".

Her motto sheds light on her own best advice to herself. In what ways should she deal with her central life problem and become more complete/whole? She would do this by remembering that it is not an easy task to become the beautiful person and intellectual she always wanted to be. She decides to draw on her past experience: her having endured so much in life has taught her to remain motivated and dedicated to her goal. Because she had not been treated with the respect and love she deserved, her only desire was to 'do unto others as she would want them to do unto her'. Lastly, remembering that she has 'survived' so much pain and suffering in her life, she believes that she can survive her current crisis as well.

Her favourite magazines and television shows reflect the occupational environment in which she wishes to act out her self-concept (a caring, helping environment where human relationships are promoted, where other people's lives are influenced in a positive manner and where education is valued). She also wants to be elegant and fashionable and to be in a position where she can live a healthier lifestyle. In her own words: "I enjoy reading magazines that provide me with an opportunity to learn something, even if this happens only to a limited extent".

Jane's preferred school subjects indicate where and to what extent she has been successful and satisfied. Her favourite subjects: Technical Drawing, because she wants to create something tangible, something that could be useful to others. Physical Science, because it provides her with an opportunity to 'prove' that she is a survivor and that she can persevere. Drama/Art, because she desires an environment where she can express who she really is and wants to be: an artist in her own right, a person who can act as a role model to others. Her least favourite subjects point to environments in which she was unsuccessful and dissatisfied in the past: languages, because she experienced an inability to express herself (read: her painful experience when she was handed a book on why being an adopted child was not 'that bad after all'). She learnt at a very early age that it was easier to deal with hurtful issues by sharing painful details with people in writing than by talking about the pain: "It seemed to me that knowledge about a topic was more dominant than expressing feelings through discussions". Books have always provided her with a 'safe zone' (holding environment) where nobody is allowed to say anything hurtful or inconsiderate. Biology and the human body, because she grew up without knowing who she was going to look like. Mens sana in corpore sano - her perception of her body as something that was rejected, broken, damaged and unrecognisable, contributed to her confused mind/spirit that longed for direction, protection and acceptance.

Jane's hobbies provide some insight into how she developed skills and strategies for dealing with life's problems. 
Camping, hiking and watching TV helped her to add meaning to a dull and unhappy life, to 'escape' from the city (reality) and a stressful working environment, to get much-needed exercise and to get in touch with her innermost feelings again. She perceived these hobbies as a way to restore harmony and balance in her life in the presence of a Higher Power. This is something that she desperately needs because "[my] life at this stage is out of control and smothering - these [coping strategies in the form of] hobbies are facilitating growth, freedom and finding a safe [sacred] place where I can find myself and express myself unconditionally".

The qualitative, descriptive and explorative nature of the study contributed to the rich and dense description of the use of early memories in life design counselling. The descriptive data suggest that this is a promising strategy that can have a lasting effect on the person concerned. The techniques used in the study seemed not only to enhance the involvement of the participant in the life design process, but also to facilitate growth, self-discovery and the writing of a life story built on an increased level of self-understanding, hope and self-respect. The participant revealed heightened self-awareness, stating that she "had acquired invaluable self-insight and courage during the course of the intervention". The usefulness of early memories in life design counselling is further highlighted by the participant's readiness to make what seemed to be an 'impossible' decision.

Savickas $(2002 ; 2005)$ maintains that career construction offers a sound theoretical framework for understanding occupational behaviour and provides a counselling strategy and methods that counsellors can use profitably with participants as they strive to achieve self-completion and make social contributions through their work. This is confirmed by the present case study, which demonstrates the usefulness of early anecdotes during career-story interviewing. However, this is not to say that the use of early anecdotes is the 'only' or 'best' method for the counselling process. In order to determine the flexibility and effectiveness of early anecdotes, this study needs to be repeated with a bigger population and culturally diverse groups.

\section{Recommendations}

Further research in this field is essential, as the findings may have implications for the practice of career counselling in various settings. Firstly, counsellors-in-training will benefit from the inclusion in curricula of career-story interviewing using the TAT. By obtaining the three early anecdotes in addition to the information gained from administering the career-story interview, counsellors stand to learn much more about clients than would otherwise have been the case. Secondly, practising counsellors will probably have to receive training in this field as well, and the Professional Board for Psychology could be expected to take the lead in this regard. Thirdly, all those involved with career counselling, irrespective of whether they are prospective or practising counsellors, will probably need training in state-of-the-art developments in career construction counselling for life designing in order to align the practice in (South) Africa with what is happening elsewhere in the world. Fourthly, it seems that teachers should be trained to administer the career story interview sans the three early anecdotes in small-group classroom settings that protect the student's privacy and integrity (Hartung, 2010) to investigate e.g., learners' interest and value as well as their strengths and weaknesses. Fifthly, counsellors may have to refer clients to an appropriate health professional if a major pathology emerges, prior to embarking on career counselling. Sixthly, the study findings seem to confirm the merits of a combined quantitative-qualitative approach to career counselling in facilitating a deeper understanding of the value of meaning making, personal agency, personal growth, (co-)construction and acceptance of personal responsibility in the career counselling process.

\section{Limitations}

This strategy is, of course, not the only way of dealing with the barriers experienced by the participant. I do, however, hope that this study will help create greater awareness of (South) African women's experiences, specifically with regard to the choice of a career and career pathways. Furthermore, because only one case study was investigated, possible generalisation of the study findings is extremely limited. Although steps were taken to enhance the trustworthiness and credibility of the study, the subjective interpretation of the researcher could also be seen as a limitation.

\section{Conclusion}

The point of departure in the study was that challenges relating to the choice of a career that a woman may experience can be addressed constructively through a co-constructive process whereby early anecdotes are used during career-story interviewing. The study revealed the unique nature of the particular participant's context, the interdependent relationship between her and her past, the subjective meaning attached to experience and the challenges currently experienced by women in South Africa.

Although the participant's circumstances and past could not be altered by the process described in this article, she revealed a 'changed' experience with regard to certain aspects of her life. Co-constructive conversation could not offer solutions to all the challenges she faced, but she became progressively more aware of the meaning she attached to her past experiences, the motivation for her behaviour and her self-perception. In addition, she showed signs of new hope for her future, as was evident from the following remark during our last conversation: "These discussions and analyses were immensely useful. By being compelled, so to speak, to reflect on issues that I had been avoiding until now, I have come to understand some of the major themes in my life. I now realise that change is possible and that I have the right and responsibility to take responsibility for my own actions".

I believe that this study should serve as a pilot for the use of early anecdotes during the life design counselling process. Replication in a larger number of cases and comparison with other case studies seem essential. I also recommend future investigations into the long-term impact of the use of early anecdotes during the life design counselling process on various populations when applied in groups.

\section{References}

Adler, A. (1932). What life should mean to you. London, England: Allen \& Unwin.

Cohen, L., Manion, L., \& Morrison, K. (2000). Research methods in education (5th ed.). London, England: Routledge.

Creswell, J. W. (2007). Qualitative inquiry and research design: Choosing among five approaches (2nd ed.). London, England: Sage.

Cronjé, P. (2010). Metaphors: The story within the story. In South African Society of Clinical Hypnosis (SASCH). Intermediate level training in Ericksonian model of hypnotherapy 
(pp. 35-44). Kensington, South Africa: South African Society of Clinical Hypnosis.

Denzin, K. N., \& Lincoln, Y. S. (1998). The landscape of qualitative research. London, England: Sage.

Durrheim, K. (1999). Research design. In M. Terre Blanche \& K. Durrheim (Eds.), Research in practice: Applied methods for the social sciences (pp. 29-53). Cape Town, South Africa: University of Cape Town Press.

Hartung, P. J. (2007). Career construction: Principles and practice. In K. Maree (Ed.), Shaping the story: A guide to facilitating narrative counselling (pp. 103-120). Pretoria, South Africa: Van Schaik.

Hartung, P. J. (2010). Identifying life-career themes with the career-story questionnaire. In K. Maree (2010), Career counselling: methods that work (pp. 176-180). Cape Town, South Africa: Juta Academic.

Maree, J. G. (2007). Class notes based on Cochran, L. (1997). Career counselling: A narrative approach. Thousand Oaks, CA: Sage.

McMillan, J. H., \& Schumacher, S. (2001). Research in education. A conceptual introduction (5th ed.). New York, NY: Addison Wesley Longman.

Nieuwenhuis, J. (2007). Analyzing qualitative data. In K. Maree (Ed.), First steps in research (pp. 98-117). Pretoria, South Africa: Van Schaik.

Porfeli, E. J. (2003). Designing lives and empowering clients: The case of Sue. Career Development Quarterly, 51, 300-305.

Saul, L. J., Snyder, T. R., \& Sheppard, E. (1956). On earliest memories. Psychoanalytic Quarterly, 25, 228-237.

Savickas, M. L. (1998). Career style assessment and counseling. In T. Sweeney (Ed.), Adlerian counseling: A practitioner's approach (4th ed., pp. 329-360). Philadelphia, PA: Accelerated Development.

Savickas, M. L. (2002). Career construction: A developmental theory of vocational behavior. In D. Brown (Ed.), Career choice and development (4th ed., pp. 149-205). San Francisco, CA: Jossey-Bass.

Savickas, M. L. (2005). The theory and practice of career construction. In S. Brown \& R. Lent (Eds.), Career development and counseling: Putting theory and research to work (pp. 42-70). New York, NY: John Wiley.

Savickas, M. L. (2006a, April). Counselling for career construction (facilitating the storied approach in career counselling: Practical implementation). Fifteenth Australian Career Counselling Conference, Sydney, Australia.

Savickas, M. L. (2006b, July). A vocational psychology for the global economy. Keynote presentation, American Psychological Association, New Orleans, LA.

Savickas, M. L. (2007). Reshaping the story of career counselling. In K. Maree (Ed.), Shaping the story - A guide to facilitating narrative counselling (pp. 1-3). Pretoria, South Africa: Van Schaik.

Savickas, M. L. (2008, July). Interactive workshop on life design counselling. Thirty-ninth International Congress of Psychology, Berlin, Germany.

Savickas, M. L. (2009a, April). Utilising early anecdotes in counselling in the 21st century. Keynote presentation, SA Society for Clinical Hypnosis, Pretoria, South Africa.
Savickas, M. L. (2009b, April). The essentials of life design counselling. Invited public lecture, University of Pretoria, Pretoria, South Africa.

Savickas, M. L. (2009c, June). The role of values in careers: Meaning and mattering in life design. Society of Vocational Psychology's 2009 Biennial Conference, Millennium Centre, University of St Louis, MO.

Savickas, M. L. (2009d). Career-story counseling. In T. J. Sweeney (Ed.), Adlerian counseling and psychotherapy: A practitioner's approach (5th ed., pp. 183-207). New York, NY: Routledge.

Savickas, M. L., Nota, L., Rossier, J., Dauwalder, J., Duarte, M. E., Guichard, J., . . V Van Vianen, A. E. M. (2009). Life designing: A paradigm for career construction in the 21st century. Journal of Vocational Behavior (2009). dol: 10.1016/j.jvb.2009.04.004.

Terre Blanche, M., \& Kelly, K. (1999). Interpretive methods. In M. Terre Blanche \& K. Durrheim (Eds.), Research in practice: Applied methods for the social sciences (pp. 123-146). Cape Town, South Africa: University of Cape Town Press.

Whitley, B. E. (2002). Principles of research in behavioural science (2nd ed.). New York, NY: McGraw-Hill.

Yapko, M. (2003). Trancework: An introduction to the practice of clinical hypnosis. New York, NY: Brunner/Mazel. 